\title{
3 Researc Sguare

\section{Evaluation of the in vivo Antihypertensive Effect and Antioxidant Activity of HL-7 and HL-10 Peptide in Mice}

\section{Zahra Setayesh-Mehr ( $\sim$ setayeshmehr@uoz.ac.ir)}

University of Zabol

Leila Vafadar Ghasemi

University of Zabol

Ahmad Asoodeh

Ferdosi University of Mashhad

\section{Research Article}

Keywords: Peptide, Antioxidant enzymes, Hypertension, Animal model

Posted Date: March 9th, 2021

DOl: https://doi.org/10.21203/rs.3.rs-260074/v1

License: (c) (1) This work is licensed under a Creative Commons Attribution 4.0 International License.

Read Full License

Version of Record: A version of this preprint was published at Molecular Biology Reports on July 21st, 2021. See the published version at https://doi.org/10.1007/s11033-021-06576-7. 


\section{Abstract}

In this study, the in vivo antioxidant and antihypertensive properties of peptides HL-7 with the sequence of YLYELR and HL-10 with the sequence of AFPYYGHHLG were identified from scorpion venom of $H$. lepturus were evaluated. To study the in vivo effects of peptides, D-galactose-induced and DOCA saltinduced mice models were used. The results of the antioxidant assay for both peptides showed that the activity of serum and liver catalase (CAT), as well as superoxide dismutase (SOD) enzymes, was significantly decreased in the D-galactose-induced group (NC), while MDA levels were increased in serum and the liver tissue samples $(p<0.01)$. Compared with the $D$-galactose-induced mice, the peptide treated mice group had a higher activity of antioxidant enzymes namely CAT and SOD, as well as a lower lipid peroxidation level. Also, the results of antihypertensive activity for both peptides showed that systolic blood pressure (SBP) and diastolic blood pressure (DBP) of the mice treated with the HL-7 and HL-10 peptides were significantly reduced in a dose-dependent manner $(\mathrm{p}<0.01)$. The administration of the HL-7 peptide at doses of $5 \mathrm{mg} / \mathrm{kg} \mathrm{BW}$ (LP1) and $15 \mathrm{mg} / \mathrm{kg} \mathrm{BW}$ (HP1) significantly diminished the mean arterial blood pressure (MAP) by $31 \mathrm{mmHg}$ and $40.47 \mathrm{mmHg}$, respectively. Accordingly, treatment of mice with the HL-10 peptide at doses of $5 \mathrm{mg} / \mathrm{kg} \mathrm{BW}$ (LP2) and $15 \mathrm{mg} / \mathrm{kg}$ BW (HP2) considerably lowered the MAP by $18.3 \mathrm{mmHg}$ and $21.93 \mathrm{mmHg}$, respectively. Our findings suggest that both the HL-7 and HL-10 peptides could be potentially utilized as antihypertensive and antioxidant components.

\section{Introduction}

Oxygen reactive species (ROS) cause a lot of damage to macromolecules such as DNA, protein, and lipids [1]. The antioxidant activity of intracellular defense system deals with the damage caused by free radicals. Antioxidant agents inhibit lipid peroxidation by reducing free radicals, stopping the production of radicals, and subsequently decomposing peroxides [1]. In some situations, such as inadequate ROS removal, antioxidant defense system fails to protect cells against oxidative stress [1]. Hence, the presence of synthetic and natural antioxidants seems necessary to prevent the deleterious effects of oxidative stress [2].

Intracellular antioxidant enzymes include primary and secondary antioxidants [3]. Superoxide dismutase (SOD), catalase (CAT), and glutathione peroxidase (GPx), which cause inactivation of ROS, are considered the primary antioxidant enzymes. Secondary antioxidant enzymes consisted of glutathione reductase (GR), glucose 6-phosphate dehydrogenase (G6PD), and glutathione S-transferase (GST) maintain their proper function through direct detoxification of ROS and continuous supply of nicotinamide adenine dinucleotide phosphate (NADP) and glutathione (GSH) for primary antioxidant enzymes [4]. The superoxide anion produced by oxidation of molecular oxygen is converted into hydrogen peroxide $\left(\mathrm{H}_{2} \mathrm{O}_{2}\right)$ by SOD enzyme. In the next step, CAT enzyme converts $\mathrm{H}_{2} \mathrm{O}_{2}$ into water [5].

Hypertension is the cause of cardiovascular disorders that affects $25 \%$ of the world's population [6]. Hypertension is one of the most important reasons for atherosclerosis, myocardial infarction, and left ventricular hypertrophy $[7,8]$. The metabolic pathway of rennin-angiotensin plays a role in controlling 
blood pressure. High blood pressure is one of the curable factors in the prevention of cardiovascular disease (CAD), so Angiotensin Converting Enzyme (ACE) is an important target for the treatment of CAD $[9,10]$. Captopril, Lisinopril, and enalapril have been identified as antihypertensive drugs with an inhibitory effect on ACE. However, such drugs have unwanted side effects [11]. Therefore, the tendency to use bioactive peptides has increased in recent decades, and research would be essential for recognizing the therapeutic effects of peptides present in animals or food resource. Some peptides isolated from scorpion venom can enhance bradykinin effect through the mechanism of ACE inhibition, which is shown for peptides with the activity of reducing blood pressure in scorpion venom of Tityus serrulatus (Peptide T) [12] and Buthus occitanus (Peptide K12) [13].

To date, no study has been conducted to show the antioxidant and antihypertensive effects of peptides isolated from Hemiscorpius lepturus scorpion venom. In the previous study, the antihypertensive and antioxidant effects of peptides coined as HL-7 and HL-10 were evaluated in vitro $[14,15]$.

The aim of this study was to measure the antioxidant activity of CAT and SOD enzymes, as well as the evaluation of MDA levels in serum and liver samples of D-galactose-induced mice to observe whether the $\mathrm{HL}-7$ and $\mathrm{HL}-10$ peptides are capable of modulating the elevated levels of ROS. Moreover, the antihypertensive potentials of those peptides were assessed in mice with hypertension induced by DOCAsalt.

\section{Materials And Methods}

\section{Chemicals}

Ascorbic acid, D-galactose, trichloroacetic acid (TCA), thiobarbituric acid (TBA), desoxycorticosterone acetate (DOCA), catalase (CAT), hydrogen peroxide $\left(\mathrm{H}_{2} \mathrm{O}_{2}\right)$, and pentobarbital sodium were obtained from Merck Chemicals Co. (Darmstadt, Germany). The SOD assay kit was applied for the measurement of SOD activity (Beyotime, Shanghai, China).

\section{Peptide Synthesis}

Solid-phase method and standard 9-fluorenylmethoxycarbonyl protection chemistry were used for the synthesis of HL-7 and HL-10 peptides with 95\% purity (GL Biochem Shanghai Ltd. Shanghai, China).

\section{Animal Procedures}

All experiments were performed on male mice weighing 20-30 gr. All stages of the experiment were conducted in accordance with the ethics committee of the University of Mashhad. This study has the of the National Committee code for Ethics in Biological Research No. IR.UM.REC.1397.063. Mice were maintained under the same light conditions ( $12 \mathrm{~h}$ light/dark cycles), temperature $\left(22 \pm 2^{\circ} \mathrm{C}\right)$, and humidity $(60 \% \pm 5)$ without any restrictions to gain access to water and food. In general, the experiments were carried out in two steps: at the first stage, the antioxidant enzymes were measured and the second stages the blood pressure of animals was examined. 


\section{Antioxidant measurement}

In the first step, 30 healthy mice (8-week-old) weighing $20.0 \pm 2.0 \mathrm{gr}$ were randomized into the control $(\mathrm{n}=$ $6)$ and aging-induced groups $(n=24)$. Mice in the control received a physiological saline solution $(0.9 \%$ $\mathrm{NaCl})(10 \mathrm{ml} / \mathrm{kg} \mathrm{BW})$ daily by subcutaneous injection for 21 days. Aging was induced by injection of 120 $\mathrm{mg} / \mathrm{kg}$ of D-galactose though subcutaneous injection once daily for 21 days. Mice in the negative control (NC) group received a subcutaneous injection of D-galactose $(120 \mathrm{mg} / \mathrm{kg})$ for 21 days. The D-galactose was dissolved in physiological saline solution $(0.9 \% \mathrm{NaCl})$. Mice in the positive control (PC) group received ascorbic acid (10 mg/kg BW) and D-galactose through subcutaneous injection for 21 days. The peptide groups coined as the P1 and P2 groups were treated with $15 \mathrm{mg} / \mathrm{kg}$ BW of the HL-7 and HL-10 peptides, respectively by subcutaneous injection and also received D-galactose through subcutaneous injection for 21 days. Treatments were performed once a week for 4 weeks.

\section{Serum and liver homogenate preparation and biochemical assays}

After 4 weeks, mice were anesthetized with pentobarbital sodium, and the activity of CAT and SOD enzymes, as well as the levels of MDA, were measured in the liver and serum of mice. In order to separate the serum, blood was centrifuged at $300 \mathrm{rpm}$ at $4^{\circ} \mathrm{C}$ for $15 \mathrm{~min}$. The obtained serum samples were stored at $-20^{\circ} \mathrm{C}$ for further analysis. After sacrificing mice, liver tissues were minced on ice by a razor blade and placed in a falcon. Then, $10 \mathrm{ml}$ phosphate buffer $(10 \mathrm{mM})$ was added to the falcon. The tissues were homogenized on the ice three times for 30s [5].

The activity of CAT was measured according to the method of Weydert and Cullen (2010) in which the decomposition of $\mathrm{H}_{2} \mathrm{O}_{2}$ is recorded at $240 \mathrm{~nm}$ at room temperature [5]. A decrease in absorbance was measured every $30 \mathrm{~s}$ in a 2-min period using the spectrophotometry method. The activity of CAT enzyme was expressed as $\mathrm{mK} / \mathrm{mg}$ protein. The analysis of SOD activity was carried out using the SOD assay kit (Beyotime, Shanghai, China). The measurement of SOD enzyme is monitored on the basis of the production of superoxide ions (by xanthine oxidation) and the reaction with tetrazolium forming a formazan color which is absorbed at $450 \mathrm{~nm}$. One unit of SOD alludes to the amount of enzyme reducing the absorbance by up to $50 \%$ at $450 \mathrm{~nm}$. The activity of SOD enzyme was expressed as $\mathrm{U} / \mathrm{mg}$ protein [16]. MDA is a crucial factor in the determination of the amount of lipid peroxidation. MDA, as a lipid peroxidation product, reacts with TBA and the pink-colored products are absorbed at $535 \mathrm{~nm}$. The TBA reaction was used to measure MDA levels in serum and liver. MDA content was expressed as $\mathrm{nmol} / \mathrm{mg}$ protein [17].

\section{Assessment of Blood pressure}

In the second step, 36 mice were divided into six groups $(n=6)$ to evaluate the effect the HL-7 and HL-10 peptides. The induction of hypertension in mice was implemented by desoxycorticosterone-DOCA-salt method [18]. In hypertension group, hypertension was induced by the subcutaneous injection of desoxycorticosterone (8 $\mathrm{mg} / \mathrm{kg} /$ week) for 21 days. Additionally, $1 \% \mathrm{NaCl}$ and $3 \%$ potassium chloride 
were added to drinking water for mice. Captopril was utilized in our experiments as a positive control to be able to compare the potency of peptides in comparison with a well-accepted drug. The peptide groups coined as the LP1, HP1 and LP2, HP2 groups were treated with the HL-7 and HL-10 peptides, respectively by subcutaneous injection and also received desoxycorticosterone through subcutaneous injection for 21 days. The experimental groups included control (water), positive control (captopril at a dosage of 5 $\mathrm{mg} / \mathrm{kg} \mathrm{BW}$ ), LP1 (HL-7 peptide at a dosage of $5 \mathrm{mg} / \mathrm{kg} \mathrm{BW}$ ), HP1 (HL-7 peptide at a dosage of $15 \mathrm{mg} / \mathrm{kg}$ BW), LP2 (HL-10 peptide at a dosage of $5 \mathrm{mg} / \mathrm{kg} \mathrm{BW}$ ), and HP2 (HL-10 peptide at a dosage of $15 \mathrm{mg} / \mathrm{kg}$ BW) by subcutaneous injection. The systolic blood pressure (SBP) and the diastolic blood pressure (DBP) of the mice were measured in awake mice by the tail cuff method before administration and also $2,4,6$, 8 , and $24 \mathrm{~h}$ after administration. This is a non-invasive blood pressure measuring system, which was clinically validated to assess blood pressure in mice and rats. It determines the tail blood volume, using a volume pressure recording sensor and occlusion tail-cuff. The values of SBP and DBP were taken as the average of $8-12$ reading. The rats are kept at $38^{\circ} \mathrm{C}$ for 20 minutes before measurement. To minimize stress on mice, all recordings are done by one person in the same situation.

\section{Statistical analysis}

Data were expressed as mean \pm SD. The analysis of the obtained data was performed using the Mstat $C$ and JMP. Comparison between groups was made by Duncan Multipe Rang Test. Values were considered statistically significant if the $p$-values were less than 0.05 .

\section{Results}

\section{Antioxidant tests}

The in vivo antioxidant activity of the $\mathrm{HL}-7$ and $\mathrm{HL}-10$ peptides was evaluated through D-galactoseinduced mice model.

\section{Antioxidant enzymes}

\section{CAT enzyme}

The results of the present study showed that the mean activity of CAT enzyme in D-galactose-induced mice was significantly reduced compared with the control group (control) $(P<0.01)$, which indicated the progression of aging in the D-galactose-treated group (Fig. 1). The activity of CAT from $7.65 \mathrm{mK} / \mathrm{mg}$ protein in the negative control group (NC) was decreased to $2.57 \mathrm{mK} / \mathrm{mg}$ protein in the D-galactosetreated group in serum samples. In line with this, the activity of CAT significantly changed from 7.53 $\mathrm{mK} / \mathrm{mg}$ protein in the negative control group (NC) to $1.99 \mathrm{mK} / \mathrm{mg}$ protein in the D-galactose-treated group when assayed in the liver tissue (Fig. 1). The activity of CAT enzyme in the ascorbic acid-treated group (PC) and peptides-treated groups, P1 (HL-7) and P2 (HL-10), was significantly increased in both serum and liver samples compared with the $D$-galactose-induced mice $(P<0.01)$, indicating the improvement of antioxidant defense system in mice receiving ascorbic acid and the HL-7 and HL-10 peptides. The CAT 
activity in serum and liver homogenates of the P1 group was close to the PC group, and the activity of CAT enzyme in the $\mathrm{P} 2$ group (HL-10 peptide) was lower than the PC and P1 groups, while its activity was higher than the D-galactose-treated group (NC) (Fig. 1).

\section{SOD enzyme}

The analysis of variance of the obtained data showed that the activity of SOD enzyme in the D-galactoseinduced mice was significantly decreased compared with the control group $(P<0.01)$ where as the activity of SOD in the PC, P1, and P2 groups was significantly higher than the D-galactose group (NC); however, the activity of SOD was lower in all four groups in comparison with the control group (Fig. 2). In all groups, the activity of CAT was higher in serum samples. An increase in the activity of serum SOD enzyme in the PC and P1 groups was approximately 2.5 folds higher than the D-galactose-treated group (NC). Correspondingly, the activity of SOD was 2 folds higher in the P2 group when compared with mice induced by D-galactose (NC). The activity of SOD in the P2 group was lower than the P1 group, and its activity was higher in the PC group compared with the P1 group (Fig. 2).

\section{MDA levels}

The analysis of the obtained results showed that treatment with D-galactose (NC) caused a significant increase in liver and serum levels of MDA $(P<0.01)$, which showed the highest amount in the liver sample of the D-galactose-treated group (Fig. 3). Compared with the control group ,the MDA level in the PC and the peptide groups, $\mathrm{P} 1$ and P2, was decreased in serum and liver homogenates (Fig. 3). The concentration of MDA was nearly the same in the PC and P1 groups, while MDA level was higher in the P2 group than that of the PC and P1 groups (Fig. 3).

\section{Assessment of Blood pressure}

The in vivo antihypertensive effect of the HL-7 and HL-10 peptides was evaluated through sub cutaneous injection of peptides to mice and eventually the measurement blood pressure by tail cuff pressure measurements. The results showed that the induction of hypertension by DOCA-salt was performed effectively, so that in all animals with hypertension, systolic blood pressure (SBP) was higher than 145 $\mathrm{mmHg}$ (Table 1). Before and after the injection, control group had no effect on the values of the SBP and DBP. The results showed that an subcutaneous injection of the $\mathrm{HL}-7$ and $\mathrm{HL}-10$ peptides at doses of 5 and $15 \mathrm{mg} / \mathrm{kg}$ BW caused a significant decrease in blood pressure in mice with hypertension compared with the control group $(P<0.01)$. The highest reduction was related to the $\mathrm{HL}-7$ peptide, so that at doses of 5 and $15 \mathrm{mg} / \mathrm{kg} \mathrm{BW}$, the mean arterial blood pressure (MAP) was decreased by $31 \mathrm{mmHg}$ and 40.47 $\mathrm{mmHg}$, respectively (Fig. 6). Before the injection, the values of the SBP and DBP were $158.1 \pm 8 \mathrm{mmHg}$ and $129.3 \pm 3 \mathrm{mmHg}$, respectively in the HP1 group (a group supposed to receive the HL-7 peptide at a dose of $15 \mathrm{mg} / \mathrm{kg} \mathrm{BW}$ ) (Table 1). After the injection of the HL-7 peptide, the values of the SBP and DBP were decreased to $118.3 \pm 4 \mathrm{mmHg}(-39.8 \mathrm{mmHg})$ and $88.5 \pm 6 \mathrm{mmHg}(-40.8 \mathrm{mmHg})$, respectively (Table 1; Fig. 4). After injection, the values of the MAP in the P2 peptide groups at doses of $5 \mathrm{mg} / \mathrm{kg} \mathrm{BW}$ (LP2) and $15 \mathrm{mg} / \mathrm{kg} \mathrm{BW}(\mathrm{HP} 2)$ reached $118 \mathrm{mmHg}(-18.3 \mathrm{mmHg})$ and $104.1 \mathrm{mmHg}(-21.93 \mathrm{mmHg})$, respectively, which were greater than that of the PC group at a dose of $5 \mathrm{mg} / \mathrm{kg}$ BW $[113 \mathrm{mmHg}(-24.5$ 
$\mathrm{mmHg}$ )] (Figs. 5 and 6). The HL-10 peptide at doses of 5 and $15 \mathrm{mg} / \mathrm{kg} \mathrm{BW}$ showed a great antihypertensive activity very close to $5 \mathrm{mg} / \mathrm{kg}$ BW captopril (Figs. 4 and 6).

Table 1

Blood pressure of mice treated with the HL-7 and HL-10 peptides or captopril

\begin{tabular}{|c|c|c|c|c|}
\hline & Before injection & & After injection & \\
\hline Treatment Group & $\mathrm{SBP}(\mathrm{mmHg})$ & $\mathrm{DBP}(\mathrm{mmHg})$ & $\mathrm{SBP}(\mathrm{mmHg})$ & $\mathrm{DBP}(\mathrm{mmHg})$ \\
\hline control & $155.3 \pm 3$ & $119.5 \pm 3$ & $156.1 \pm 6$ & $118.7 \pm 1$ \\
\hline PC & $157.1 \pm 4$ & $127.7 \pm 6.1$ & $132.4 \pm 4.9$ & $103.3 \pm 3$ \\
\hline LP1 & $152.2 \pm 2$ & $116.1 \pm 6.5$ & $127 \pm 1.2$ & $82.2 \pm 3$ \\
\hline HP1 & $158.1 \pm 8$ & $129.3 \pm 3$ & $118.3 \pm 4$ & $88.5 \pm 6$ \\
\hline LP2 & $162 \pm 3$ & $123.6 \pm 3.8$ & $145.9 \pm 6$ & $104.2 \pm 3$ \\
\hline HP2 & $145.5 \pm 1.7$ & $116.3 \pm 3.4$ & $125.3 \pm 5.9$ & $93.5 \pm 3$ \\
\hline
\end{tabular}

\section{Discussion}

Oxygen reactive species (ROS) cause lipid peroxidation and subsequently damage to vital intracellular components, including proteins REF (Related Elongation Factor). Oxidative stress is increased as living organisms become aged; hence, the use of antioxidants is necessary in order to reduce the harmful effects of oxidative stress associated with aging $[19,20]$. To date, no research has been established to investigate the activity of antioxidant peptides extracted from the scorpion venom against oxidative stress. Hence, in this study, D-galactose-induced mice was used to evaluate the antioxidant activity of the extracted peptides namely $\mathrm{HL}-7$ and $\mathrm{HL}-10$ from $\mathrm{H}$. lepturus scorpion venom. The results showed that the activity of CAT and SOD enzymes was decreased significantly in D-galactose-induced mice when compared with the control group $(p<0.01)$, while the level of MDA, as the product of lipid peroxidation, was increased in the D-galactose-treated groups (Figs. 1 and 2). The concentration of MDA in the PC, P1, and $\mathrm{P} 2$ groups was lower than the control group and mice receiving D-galactose, suggesting the effective antioxidant activity of HL-7 and HL-10 peptides. Studies have shown that the injection of D-galactose into mice causes similar changes in the senescence process such as the weakness of the immune system REF, neurological deficiency REF, and decreased activity of antioxidant enzymes [21, 22]. Zhuo et al., (2017) examined the effects of peptides extracted from mussle by intragastric gavage on D-galactoseinduced 8-month-old mice. The results showed that lipid and glucose homeostasis was impaired in galactose-induced mice and also increased damage caused by reactive oxygen species and the aging process. Peptides extracted from mussle improved glucose and lipid metabolism by increasing hepatic glycogen, increasing serum high-density lipoprotein (HDL) levels, reducing insulin resistance, and 
lowering serum glucose and triglyceride levels [23]. SOD is an effective enzyme playing a pivotal role in the antioxidant system of the cell REF. This enzyme is capable of eliminating superoxide radicals by balancing between the production and the elimination of ROS and consequently protecting the cell against damage REF. Another important enzyme in the protection system is CAT REF. CAT reacts with $\mathrm{H}_{2} \mathrm{O}_{2}$, neutralizes the over-reactivity of hydrogen peroxide, and converts that into water and oxygen [5]. In this study, the HL-7 and HL-10 peptides prevent a decrease in the activity of CAT and SOD both in the serum and liver of D-galactose-induced mice. The HL-7 peptide had a higher rate of antioxidant and antiaging effect in comparison with the $\mathrm{HL}-10$ peptide. A number of studies have shown that the antioxidant activity of peptides can be attributed to the presence of the high numbers of hydrophobic amino acids [24]. Research has shown that the main ingredient in bee venom is a 26 -amino acid peptide called melittin. This peptide was extracted by high-performance liquid chromatography (HPLC). The results showed that melittin was the main compound in the venom, which caused high antioxidant properties in bee venom (Apis dorsata) extract Therefore, bee venom extract can have potential applications in cosmetic products [25]. Reports have shown that animal venoms have a high selectivity for molecular purposes and consequently potential therapeutic properties due to their enzymes, proteins and bioactive peptides. Hossam Ebaid et al., (2014) found that Samsum ant (Pachycondyla sennaarensis) venom was a powerful antioxidant agent that scavenged oxygen free radicals and thus neutralized CCL4-Induced Nephrotoxicity in vivo [26]. In the present study, due to the high hydrophobicity of the HL-7 peptide (42\%) in comparison with the peptide $\mathrm{HL}-10(30 \%)$, the antioxidant activity of the $\mathrm{HL}-7$ peptide was more pronounced over the peptide HL-10. In line with this, studies have indicated that there is an inverse relationship between antioxidant potency and the molecular weight of peptides. In the present study, the HL-7 peptide possessed a lower molecular weight $(927.30 \mathrm{Da})$ and a higher antioxidant activity compared with the HL-10 peptide (1161.41 Da).

In our previous study, the antihypertensive effect of the HL-7 and HL-10 peptides was reported in vitro, and the $\mathrm{IC}_{50}$ values of those peptides were $9.37 \mu \mathrm{M}$ and $17.22 \mu \mathrm{M}$, respectively. The results of the molecular docking confirmed the experimental results and showed that both peptides, as competitive inhibitors, inhibit ACE by binding to the active sites of the enzyme $[13,14]$. In order to test whether the previous report can be replicated when the HL-7 and HL-10 peptides are used in vivo, we applied both peptides in DOCA salt-induced mice model to monitor their potency and ability in the reduction of the blood pressure. We also compared the antihypertensive potentials of peptides with captopril, which is considered a well-accepted drug against hypertension. Our findings showed that the HL-7 and HL-10 peptides resulted in a significant decrease in the blood pressure in hypertensive mice compared with the control group in a dose-dependent manner. The highest reduction was found in the MAP at doses of 5 $\mathrm{mg} / \mathrm{kg} \mathrm{BW}$ and $15 \mathrm{mg} / \mathrm{kg} \mathrm{BW}$ of the HL-7 peptide (Fig. 6). This result is valuable because the MAP values of mice treated with the HL-7 peptide were significantly lower than captopril at a dose of $5 \mathrm{mg} / \mathrm{kg} \mathrm{BW}$. Mice treated with the $\mathrm{HL}-10$ peptide at doses of 5 and $15 \mathrm{mg} / \mathrm{kg} \mathrm{BW}$, exhibited a lower change in the blood pressure when compared with the control mice which received captopril and those treated with the $\mathrm{HL}-70$ at both doses of 5 and $15 \mathrm{mg} / \mathrm{kg} \mathrm{BW}$ (Figs. 4 and 6). An isolated peptide from the venom of Tityus serrulatus scorpion (peptide $\mathrm{T}$ ) was recognized as the first peptide with bradykinin-potentiating activity 
[11]. It has also been reported that the bradykinin-potentiating activity of peptide $\mathrm{K} 12$ isolated from the venom of Buthus occitanus scorpion is probably due to the inhibition of ACE [12]. Another peptide named TsHpt-I, which is isolated from the scorpion venom shows bradykinin-potentiating activity by a different mechanism in the inhibition of the ACE enzyme. This peptide likely triggers the release of nitric oxide and subsequently facilitate the dilation of the blood vessels, resulting in a decrease in the blood pressure and an increase in the bradykinin effect [27]. Our previous results showed that the peptide HL-7 $(9.37 \mu \mathrm{M})$ is a potent enzyme inhibitor for ACE in comparison with the peptide HL-10 $(17.22 \mu \mathrm{M})$ and the results were confirmed by the molecular docking [14]. The in vivo results of the current research corroborate the in vitro results of our previous study, as well as the findings of the molecular docking.

\section{Conclusion}

In this study, the in vivo antioxidant and antihypertensive effects of the HL-7 and HL-10 peptides were evaluated on mice induced by the administration of D-galactose and DOCA salt, respectively. The results showed that both peptides, as antioxidant agents, increase the activity of antioxidant enzymes (CAT and SOD) and reduce MDA levels through the upregulation of antiaging factors in mice treated with the HL-7 and $\mathrm{HL}-10$ peptides. Also, the measurement of the blood pressure implicated that both peptides had a higher rate of antihypertensive activity in comparison with captopril in hypertensive mice. Hence, the HL-7 and $\mathrm{HL}-10$ peptides can be considered valuable candidates for the future drug design.

\section{Declarations}

\section{Acknowledgements}

The authors appreciate the support provided by University of Zabol (Grant code: UOZ-GR-9718-96, $1399 / 07 / 28)$.

\section{Conflict of Interest}

Zahra Setayesh-Mehr, Leila Vafadar Ghasemi and Ahmad Asoodeh declare that they have no conflict of interest.

\section{References}

1. Lu W, Ogasawara MA, Huang P (2007) Models of reactive oxygen species in cancer. Drug Discov Today Dis Models 4:67-73. https://doi.org/10.1016/j.ddmod.2007.10.005.

2. Mates JM, Perez-Gomez C, Nunez de Castro I (1999) Antioxidant enzymes and human diseases. Clin Biochem 32:595-603. https://doi.org/10.1016/s0009-9120(99)00075-2.

3. Lghodaro OM, Akinloye OA (2018) First line defence antioxidants-superoxide dismutase (SOD), catalase (CAT) and glutathione peroxidase (GPX): Their fundamental role in the entire antioxidant 
defence grid. Alexandria Journal of Medicine. 54:287-293.

https://doi.org/10.1016/j.ajme.2017.09.001.

4. Shafaq N (2012) An Overview of Oxidative Stress and Antioxidant Defensive System. Open Access Scientific Reports. 1:1-9. https://doi.org/10.4172/scientificreports.413.

5. Weydert CJ, Cullen JJ (2010) Measurement of superoxide dismutase, catalase and glutathione peroxidase in cultured cells and tissue. Nat Protoc 5:55-61. https://doi.org/ 10.1038/nprot.2009.197.

6. Yadav S, Boddula R, Genitta G (2008) Prevalence \& risk factors of pre-hypertension \& hypertension in an affluent north Indian population. Indian J Med Res 128:712-720.

7. Hajjar I, Kotchen JM, Kotchen TA (2006) Hypertension: trends in prevalence, incidence, and control. Annu Rev Public Health 27:465-490. https://doi.org/10.1146/annurev.publhealth.27.021405.102132.

8. Benner JS, Smith TW, Petrilla AA, Klingman D, Goel S, Tang SS, Wong ND (2008) Estimated prevalence of uncontrolled hypertension and multiple cardiovascular risk factors and their associated risk of coronary heart disease in the United States. J Am Soc Hypertens 2:44-53. https://doi.org/10.1016/j.jash.2007.07.001.

9. Anthony CS, Masuyer G, Sturrock ED, Acharya KR (2012) Structure based drug design of angiotensinI converting enzyme inhibitors. Curr Med Chem 19:845-855.

https://doi.org/10.2174/092986712799034950.

10. Dive V, Cotton JL, Yiotakis A, Michaud A, Vassiliou S, Jiracek J, Vazeux G, Chauvet MT, Cuniasse P, Corvol P (1999) RXP 407, a phosphinic peptide, is a potent inhibitor of angiotensin I converting enzyme able to differentiate between its two active sites. Biochem 96:4330-4335.

11. Natesh R, Schwager SLU, Sturrock ED, Ravi Acharya K (2003) Crystal structure of the human angiotensin-converting enzyme-lisinopril complex. Nature 421:551-554.

https://doi.org/10.1038/nature01370.

12. Ferreira LAF, Alves EW, Henriques OB (1993) Peptide T, a novel bradykinin potentiator isolated from Tityus serrulatus scorpion venom. Toxicon 31:941-947. https://doi.org/ 10.1016/00410101(93)90253-f.

13. Abdel-Raheim MA, Meki AR, Nassar AY, Rochat H (1995) A Bradyknin-Potentiating Peptide (Peptide K12) isolated from the venom of egyptian scorpion Buthus occitanus. Peptides 16:1359-1365. https://doi.org/10.1016/0196-9781(95)02036-5.

14. Setayesh-Mehr Z, Asoodeh A (2017a) Biochemical characterization of HL-7 and HL-10 peptides identified from scorpion venom of Hemiscorpius lepturus. Int J Pept Res Ther 24:421-430. https://doi.org/10.1007/s10989-017-9625-1.

15. Setayesh-Mehr Z, Asoodeh A (2017b) The inhibitory activity of HL-7 and HL-10 peptide from scorpion venom (Hemiscorpius lepturus) on angiotensin converting enzyme: Kinetic and docking study. Bioorg Chem 75:30-37. https://doi.org/10.1016/j.bioorg.2017.09.006.

16. Hu YY, Xing LJ, Zhou GH, Zhang WG (2016) Antioxidant activity of crude peptides extracted from drycured Jinhua Ham. J Food Nutr Res 4:377-387. https://doi.org/ 10.12691/jfnr-4-6-6. 
17. Ohkawa H, Ohishi N, Yagi K (1979) Assay for lipid peroxides in animal tissues by thiobarbituric acid reaction. Anal Biochem 95:351-358. https://doi.org/10.1016/0003-2697(79)90738-3.

18. Yamada M, Hishida A, Honda N (1992) Effects of desoxycorticosterone acetate (DOCA) plus saline drinking on gentamicin-mediated nephropathy in rats. Ren Fail 14:499-505. https://doi.org/10.3109/08860229209047659.

19. Valko M, Rhodes CJ, Moncol J, Izakovic MM, Mazur M (2006) Free radicals, metals and antioxidants in oxidative stress-induced cancer. Chem Biolog Interact 160:1-40. https://doi.org/10.1016/j.cbi.2005.12.009.

20. Bronsart L, Nguyen L, Habtezion A, Contag C (2016) Reactive Oxygen Species Imaging in a Mouse Model of Inflammatory Bowel Disease. Mol Imaging Biol 18:473-478.

21. Ranathunga S, Rajapakse N, Kim SK (2006) Purification and characterization of antioxidantative peptide derived from muscle of conger eel (Conger myriaster). Eur Food Res Technol 222:310-315.

22. Sonz X, Bao M, Li D (1999) Advanced glycation in D-galactose induced mouse aging model. Mech Ageing Dev 108:239-251. https://doi.org/10.1016/s0047-6374(99)00022-6.

23. Zhou Y, Xu Q, Dong Y, Zhu S, Song S, Sun N (2017) Supplementation of mussel peptides reduces aging phenotype, lipid deposition and oxidative stress in D-galactose-induce aging mice. J Nutr Health Aging 21:1314-1320. https://doi.org/ 10.1007/s12603-016-0862-3.

24. Mendis E, Rajapakse N, Byun HG, Kim SK (2005) Investigation of jumbo squid (Dosidicus gigas) skin gelatin peptides for their in vitro antioxidant effects. Life Sci 77:2166-2178. https://doi.org/10.1016/j.lfs.2005.03.016.

25. Somwongin S, Chantawannakul P, Chaiyana W (2018) Antioxidant activity and irritation property of venoms from Apis species. Toxicon 145:32-39. https://doi.org/10.1016/j.toxicon.2018.02.049.

26. Ebaid H, Al-Tamimi J, Hassan I, Alhazza I, Al-Khalifa M (2014) Antioxidant bioactivity of Samsum ant (Pachycondyla sennaarensis) venom protects against CCLX-induced nephrotoxicity in mice. Oxid Med Cell Longev 763061. https://doi.org/ 10.1155/2014/763061.

27. Ortiz E, Gurrola GB, Schwartz EF, Possani LD (2015) Scorpion venom components as potential candidates for drug development. Toxicon 93:125-135. https://doi.org/ 10.1016/j.toxicon.2014.11.233.

\section{Figures}




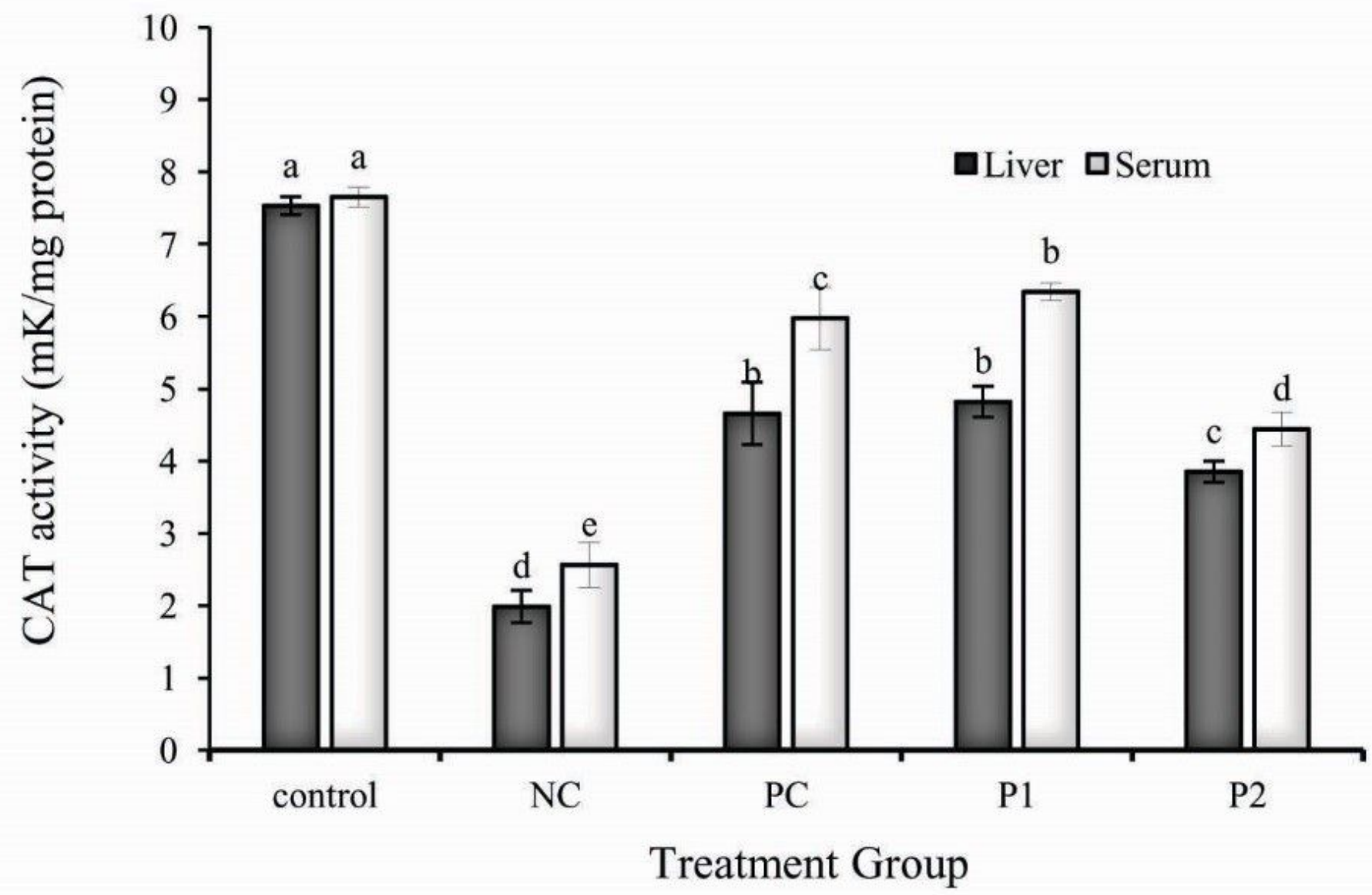

Figure 1

The effect of the HL-7 and HL-10 peptides and ascorbic acid on the activity of CAT enzyme in liver and serum samples. Values are the means of three experiments. The different letters between the means show a significant difference $(\mathrm{P}<0.01)$. NC: Negative Control; PC: Positive Control; P1: HL-7 peptide; P2: HL-10 peptide. 


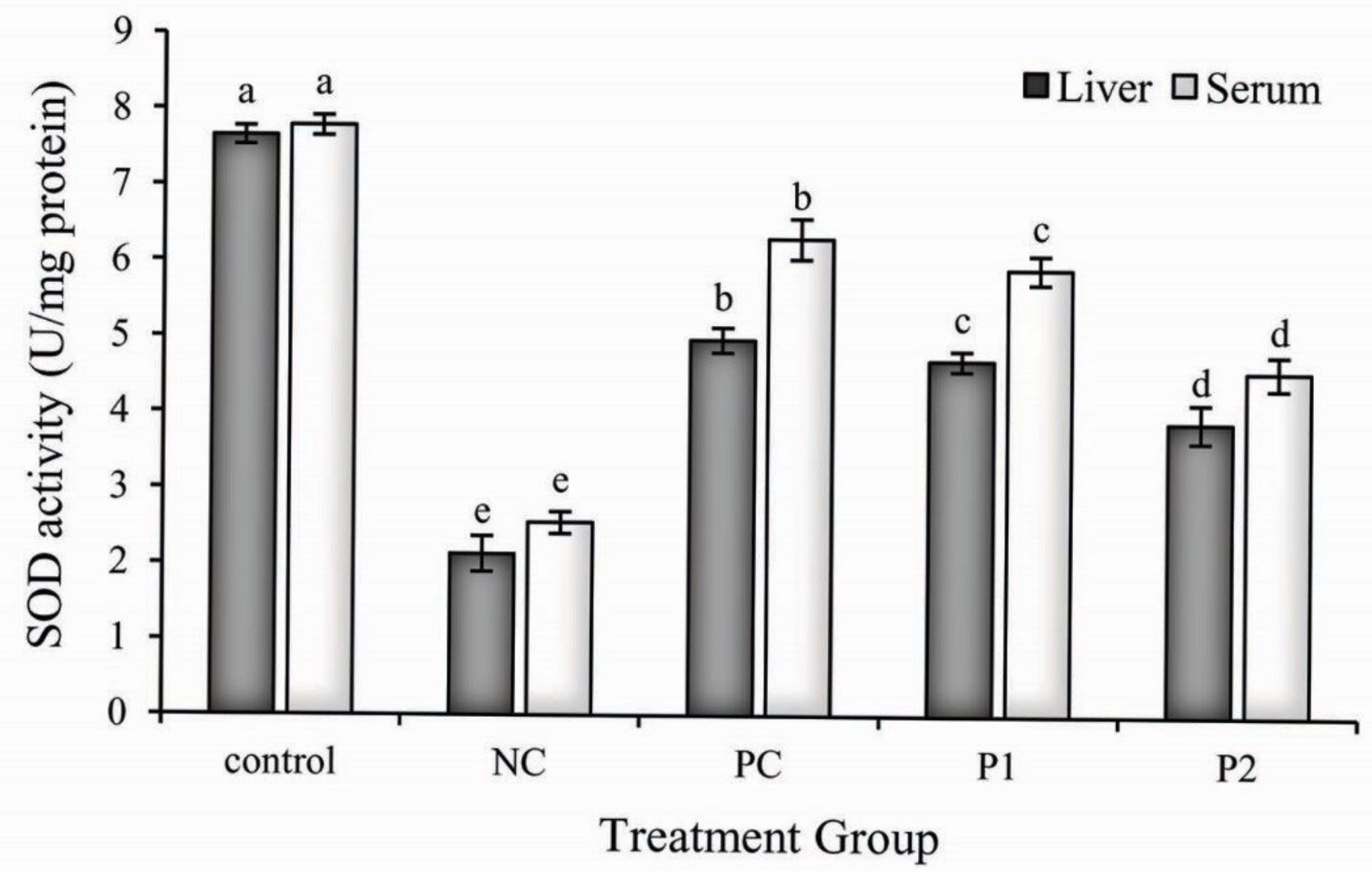

Figure 2

The study of SOD activity in serum and liver samples of mice treated with D-galactose (NC), ascorbic acid (PC), and the HL-7 (P1) and HL-10(P2). Values represent the mean of three experiments in the experimental groups. Different letters between the means indicate a statistically significant difference $(P<0.01)$. 


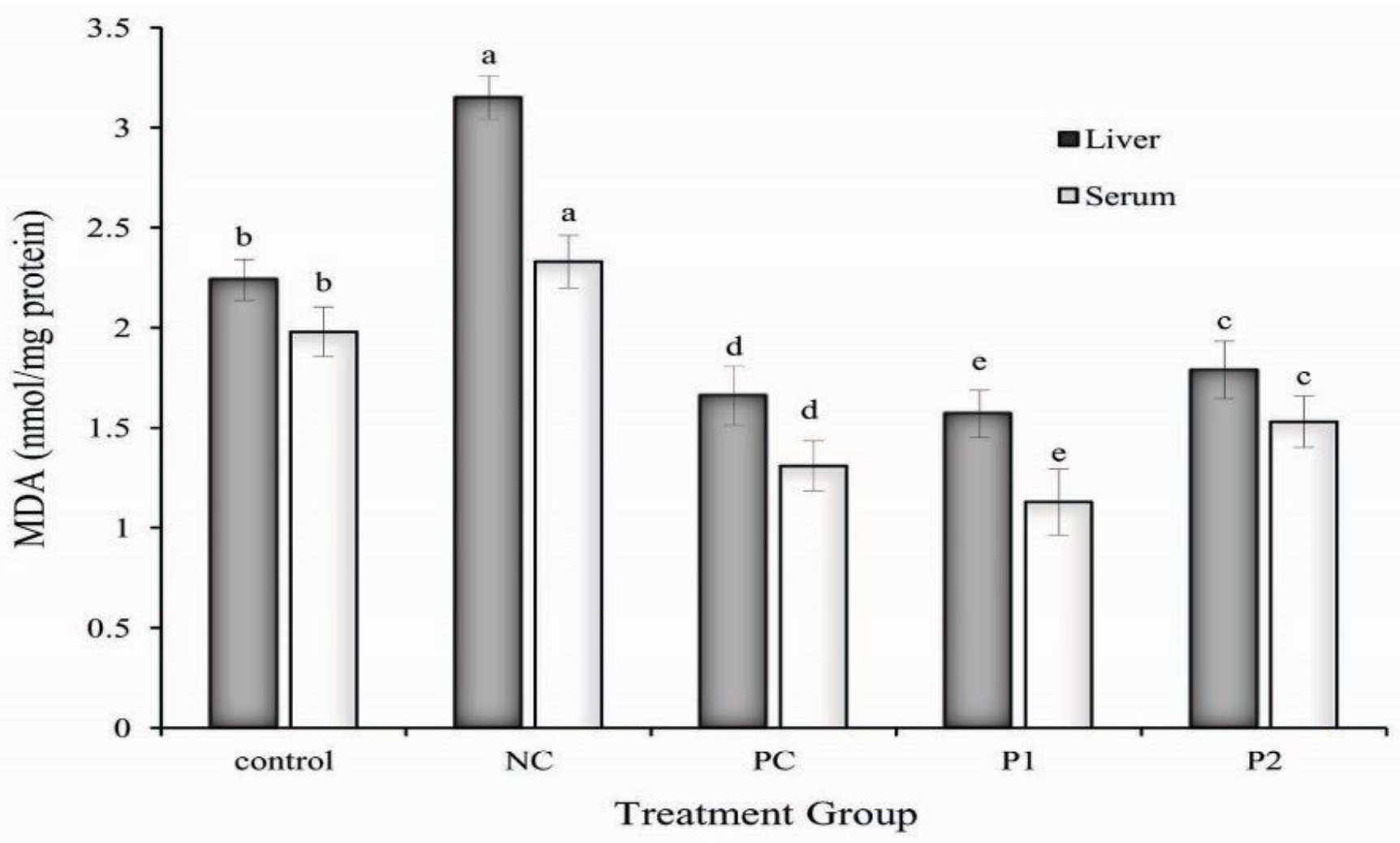

Figure 3

Comparison of MDA levels in different treatment groups. NC: Negative Control; PC: Positive Control; P1: $\mathrm{HL}-7$ peptide; $\mathrm{P} 2$ : $\mathrm{HL}-10$ peptide. Values represent the mean of three tests in experimental groups. Different letters between the means indicate a statistically significant difference $(P<0.01)$. 


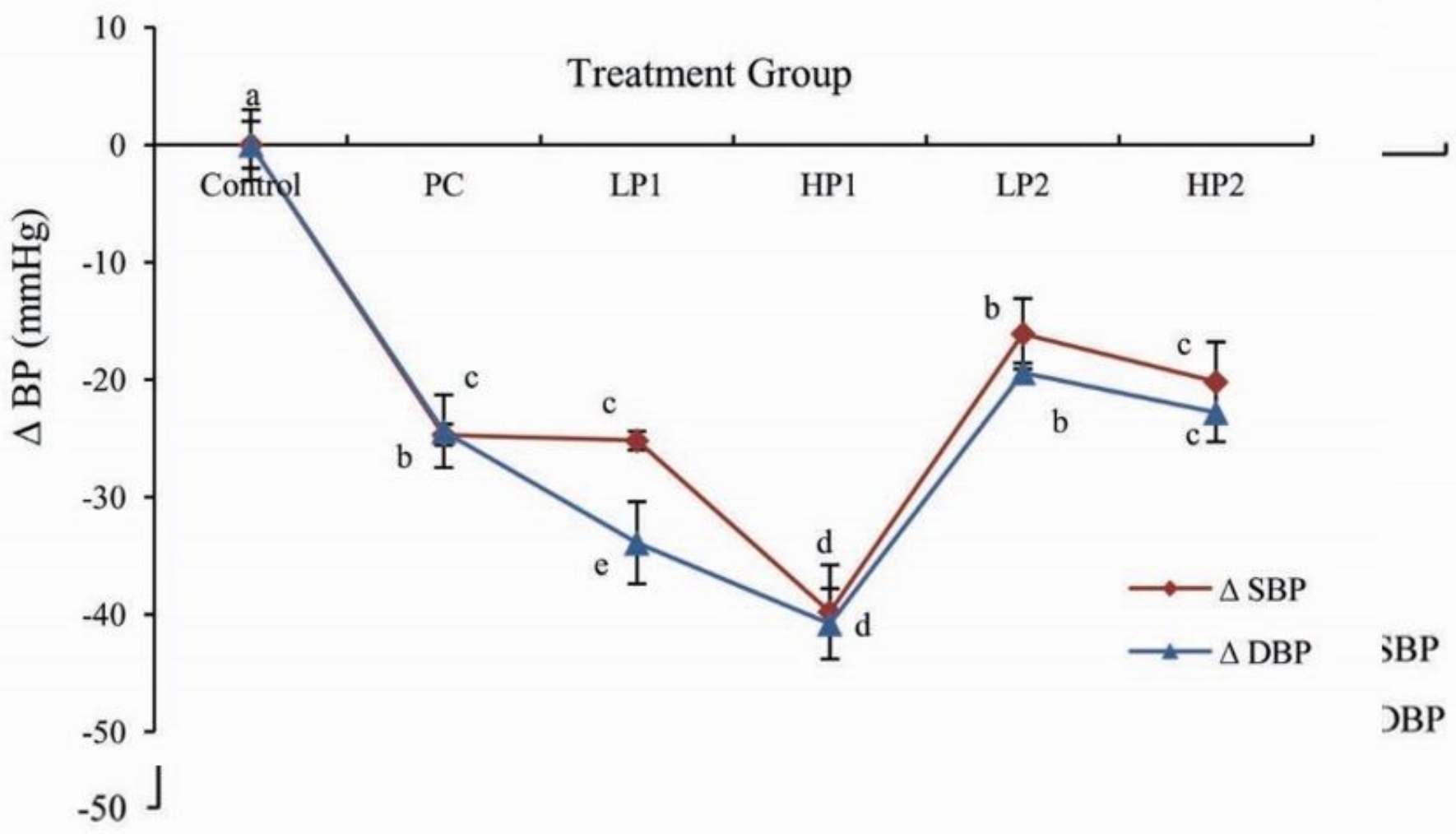

\section{Figure 4}

Changes in the amounts of SBP and DBP after the injection of the synthetic peptides and captopril in hypertensive mice. LP1: HL-7 peptide (5 mg/kg BW); HP1: HL-7 peptide (15 mg/kg BW); LP2: HL-10 peptide (5 mg/kg BW); HP2: HL-10 peptide (15 mg/kg BW). Values are the means of three experiments. The different letters between the means indicate a significant difference $(P<0.01)$. 


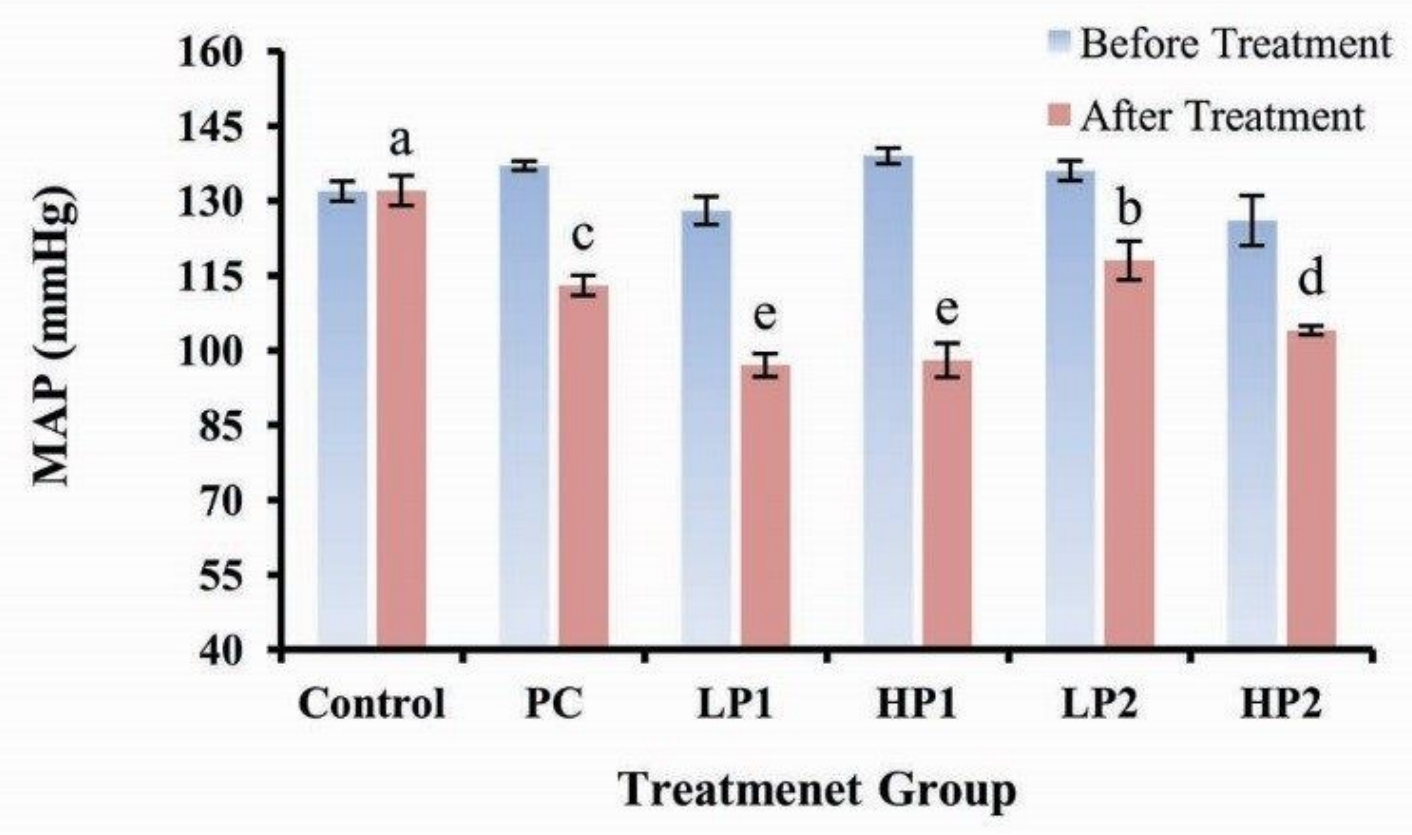

Figure 5

Changes in the amounts of MAP before and after the injection of the synthetic peptides and captopril in hypertensive mice. PC: Positive Control (captopril) (5 mg/kg BW); LP1: HL-7 peptide (5 mg/kg BW); HP1: HL-7 peptide (15 mg/kg BW); LP2: HL-10 peptide (5 mg/kg BW); HP2: HL-10 peptide (15 mg/kg BW). Values are the means of three experiments. The different letters between the means indicate a significant difference $(P<0.01)$. 


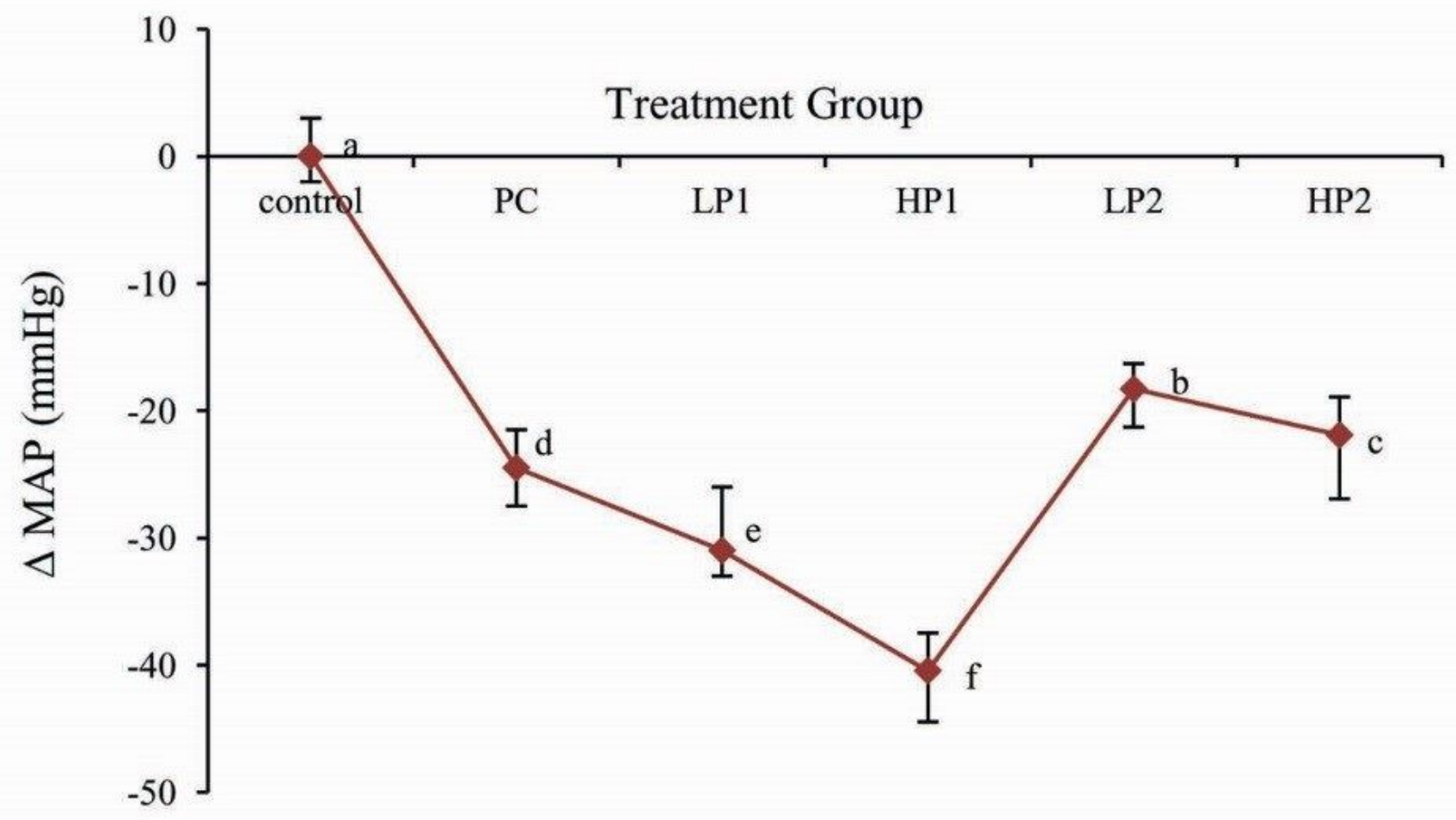

Figure 6

Changes in the amounts of the MAP after an intravenous injection of the synthetic peptides and captopril in hypertensive mice. The LP1 and HP1 represent groups of mice treated with the HL-7 peptide at doses of 5 and $15 \mathrm{mg} / \mathrm{kg} \mathrm{BW}$, respectively. The LP2 and HP2 represent groups of mice treated with the HL-10 peptide at doses of 5 and $15 \mathrm{mg} / \mathrm{kgBW}$, respectively. Values are the means of three experiments. The different letters between the means indicate a significant difference $(P<0.01)$.

\section{Supplementary Files}

This is a list of supplementary files associated with this preprint. Click to download.

- graphicalabstract1 copy.jpg 